\title{
Metastatic tumours to the conjunctiva: report of 10 cases
}

\author{
Hayyam Kiratli, Carol L Shields, Jerry A Shields, Patrick DePotter
}

\begin{abstract}
Aims/Background-Ten patients with metastatic tumours to the conjunctiva and the clinical aspects of this rare form of ocular metastasis are described in this study.

Method-All patients with ocular and adnexal metastatic tumours referred to an ocular oncology service were reviewed and those having conjunctival metastases were studied for the site of their primary tumour, clinical features, and treatment of the conjunctival tumour, associated ocular and systemic findings, and the patients' outcome.
\end{abstract}

Results-The primary malignancy was carcinoma of the breast in four, lung cancer in two, laryngeal carcinoma in one, cutaneous melanoma in two, and unknown in one patient. The conjunctival metastases appeared after the primary tumour over a mean period of 44 (8-130) months. They were solitary in eight cases, located in bulbar conjunctiva in six, palpebral conjunctiva in two, and in limbus and forniceal conjunctiva in one patient each. The tumour was yellow in colour in seven patients, red in two, and brown in one. Eight patients also had metastases to other ocular structures. Seven patients received external beam radiotherapy to the affected eye, two were managed by excisional biopsy, and one with chemotherapy. The mean survival after the diagnosis of conjunctival metastasis was nine (range 2-26) months.

Conclusion-Metastatic tumours to the conjunctiva appear at an advanced stage of the systemic disease when there are other ocular and organ metastases. The presence of a conjunctival mass in a patient with a prior systemic cancer should alert the ophthalmologist to the possibility of a conjunctival metastasis and evaluation should be pursued.

(Br F Ophthalmol 1996; 80: 5-8)

Metastatic tumours to the eye and adnexa occur in $4-12 \%$ of all patients with cancer. ${ }^{12}$ Metastases to the eye and adnexa are generally found in the intraocular structures (64\%), orbit $(29 \%)$, optic nerve $(3 \%)$, and eyelids $(2 \%)^{3}$ and usually present in the late course of the disease. ${ }^{4}$ Metastatic tumours to the conjunctiva are exceedingly rare and are usually not even mentioned in reviews on ocular metastases. ${ }^{1-46}$

There have been very few reports on the subject of conjunctival metastasis. One series described five patients with metastatic cutaneous melanoma to the conjunctiva and two patients with primary conjunctival melanoma that showed intralymphatic spread to other parts of the conjunctiva. ${ }^{7}$ We report our experience with conjunctival metastasis in 10 patients and summarise the clinical aspects and treatment of this condition.

\section{Patients and methods}

We reviewed the clinical records of all patients with ocular and adnexal metastasis who were evaluated and managed at the Ocular Oncology Service at Wills Eye Hospital between February 1974 and February 1994. Those with the diagnosis of conjunctival metastasis were selected for further study. We specifically excluded those patients with conjunctival involvement with lymphoid or leukaemic malignancies and those with intraocular extension of uveal melanoma or retinoblastoma. This study was limited to conjunctival metastasis from distant non-contiguous solid tumours. The data evaluated include age, sex, eye(s) involved, visual acuity, clinical appearance, tumour dimensions, ocular treatment, and outcome. The site of the primary tumour, treatment of the primary tumour, and distant metastases were also reviewed. The survival status of each patient was determined.

\section{Results}

Ten patients were found to have conjunctival metastases. General data on our patients are shown in Table 1 . Of the 10 patients, seven were women and three were men. The age of the patients at the time of diagnosis of the conjunctival tumour ranged from 36 to 70 years with a mean age of 56 years and median age of 56 years.

The site and type of the primary tumour that metastasised to the conjunctiva was breast carcinoma in four patients, lung in two, cutaneous melanoma in two, and laryngeal 
Table 1 Systemic findings in 10 patients with conjunctival metastases

\begin{tabular}{|c|c|c|c|c|c|c|c|}
\hline $\begin{array}{l}\text { Patient } \\
\text { number }\end{array}$ & $\begin{array}{l}\text { Age at } \\
\text { eye } \\
\text { diagnosis }\end{array}$ & Sex & $\begin{array}{l}\text { Site of } \\
\text { primary }\end{array}$ & $\begin{array}{l}\text { Treatment of primary } \\
\text { tumour }\end{array}$ & $\begin{array}{l}\text { Interval primary } \\
\text { to conjunctival } \\
\text { metastases } \\
\text { (months) }\end{array}$ & $\begin{array}{l}\text { Non-ocular metastases } \\
\text { at the time of } \\
\text { conjunctival metastasis }\end{array}$ & $\begin{array}{l}\text { Systemic status } \\
\text { (months from } \\
\text { eye diagnosis) }\end{array}$ \\
\hline 1 & 56 & $\mathbf{F}$ & Breast & $\begin{array}{l}\text { Mastectomy, } \\
\text { chemotherapy }\end{array}$ & 72 & Ribs, subcutaneous & $\begin{array}{l}\text { Dead from } \\
\text { metastasis (14) }\end{array}$ \\
\hline 2 & 47 & $\mathbf{F}$ & Breast & Mastectomy & 130 & Liver, spine & $\begin{array}{l}\text { Dead from } \\
\text { metastasis (11) }\end{array}$ \\
\hline 3 & 36 & $\mathbf{F}$ & Breast & Mastectomy & 18 & Scalp, lung, chest wall & $\begin{array}{l}\text { Dead from } \\
\text { metastasis (5) }\end{array}$ \\
\hline 4 & 69 & $\mathrm{~F}$ & Breast & $\begin{array}{l}\text { Mastectomy, EBRT, } \\
\text { chemotherapy }\end{array}$ & 36 & None & $\begin{array}{l}\text { Dead from } \\
\text { metastasis (26) }\end{array}$ \\
\hline 5 & 54 & $\mathbf{F}$ & $\begin{array}{l}\text { Cutaneous } \\
\text { melanoma }\end{array}$ & Excisional biopsy & 71 & $\begin{array}{l}\text { Spine, lung, subcuta- } \\
\text { neous }\end{array}$ & $\begin{array}{l}\text { Dead from } \\
\text { metastasis (16) }\end{array}$ \\
\hline 6 & 70 & $\mathbf{M}$ & $\begin{array}{l}\text { Cutaneous } \\
\text { melanoma }\end{array}$ & $\begin{array}{l}\text { Excisional biopsy, } \\
\text { EBRT }\end{array}$ & 15 & $\begin{array}{l}\text { Chest wall, lymph } \\
\text { nodes }\end{array}$ & $\begin{array}{l}\text { Dead from } \\
\text { metastasis (2) }\end{array}$ \\
\hline 7 & 48 & $\mathbf{M}$ & Lung & $\begin{array}{l}\text { EBRT, chemother- } \\
\text { apy }\end{array}$ & 8 & Bone, subcutaneous & $\begin{array}{l}\text { Dead from } \\
\text { metastasis (2) }\end{array}$ \\
\hline 8 & 56 & $\mathbf{F}$ & Lung & Resection, EBRT & 11 & None & Alive (20) \\
\hline 9 & 60 & $\mathbf{F}$ & Larynx & $\begin{array}{l}\text { Laryngectomy, } \\
\text { EBRT }\end{array}$ & 43 & Scalp, subcutaneous & $\begin{array}{l}\text { Dead from } \\
\text { metastasis (2) }\end{array}$ \\
\hline 10 & 62 & $\mathbf{M}$ & Unknown & None & Unknown & $\begin{array}{l}\text { Oesophagus, liver } \\
\text { subcutaneous }\end{array}$ & $\begin{array}{l}\text { Dead from } \\
\text { metastasis (2) }\end{array}$ \\
\hline
\end{tabular}

F: female, M: male, EBRT=external beam radiotherapy.

Table 2 Ocular findings in 10 patients with conjunctival metastases

\begin{tabular}{|c|c|c|c|c|c|c|c|c|c|}
\hline \multirow{2}{*}{$\begin{array}{l}\text { Patient } \\
\text { number }\end{array}$} & \multirow{2}{*}{$\begin{array}{l}\text { Eye } \\
(L / R)\end{array}$} & \multirow[b]{2}{*}{$V A$} & \multirow{2}{*}{$\begin{array}{l}\text { Ocular } \\
\text { symptom }\end{array}$} & \multirow{2}{*}{$\begin{array}{l}\text { Other ocular } \\
\text { metastasis }\end{array}$} & \multicolumn{3}{|c|}{ Conjunctival tumour } & \multirow[b]{2}{*}{ Treatment } & \multirow{2}{*}{$\begin{array}{l}\text { Tumour } \\
\text { status }\end{array}$} \\
\hline & & & & & Number & Location & Size $(\mathrm{mm})$ & & \\
\hline 1 & $\mathbf{R}$ & $20 / 25$ & Red eye & Choroid, orbit & 1 & Bulbar & $4 \times 4 \times 2$ & EBRT & Regressed \\
\hline 2 & L & $20 / 20$ & FB sensation & None & 1 & Bulbar & $12 \times 12 \times 3$ & Excision, EBRT & Regressed \\
\hline 3 & L & $20 / 20$ & Mass & None & $i$ & Palpebral & $7 \times 5 \times 3$ & Excision & Regressed \\
\hline 4 & $\mathbf{R}$ & $20 / 25$ & Red eye & Choroid, iris & 1 & Bulbar & $5 \times 5 \times 2$ & EBRT & Regressed \\
\hline 5 & L & HM & Pain & Iris & 7 & Limbal & $2 \times 2 \times 2$ & Chemo & Progressed \\
\hline 6 & $\bar{L}$ & $20 / 80$ & Red eye & Ciliary body, iris & 2 & Palpebral & $2 \times 2 \times 2$ & EBRT & No change \\
\hline 7 & $\bar{L}$ & $20 / 20$ & FB sensation & Orbit & 1 & Bulbar & $12 \times 7 \times 4$ & None & NA \\
\hline 8 & $\mathrm{~L}$ & $20 / 40$ & Mass & Isis & 1 & Bulbar & $6 \times 6 \times 2$ & EBRT, enucleation & Progressed \\
\hline 9 & $\mathbf{R}$ & $20 / 20$ & Red eye & Choroid, iris & 1 & Bulbar & $8 \times 6 \times 2$ & EBRT & Regressed \\
\hline 10 & L & $20 / 20$ & Tearing & Iris & 1 & Fornix & $3 \times 3 \times 2$ & EBRT & No change \\
\hline
\end{tabular}

$\mathrm{VA}=$ visual acuity, $\mathrm{EBRT}=$ external beam radiotherapy, $\mathrm{HM}=$ hand movements, $\mathrm{NA}=$ not available, $\mathrm{FB}=$ foreign body, Chemo= chemotherapy.

adenocystic carcinoma in one (Table 1). In one case (No 10) the site of the primary tumour was never clearly determined. This patient also had metastatic carcinoma to oesophagus, liver, and subcutaneous tissues and died of disseminated metastasis 2 months later. At the time the diagnosis of the conjunctival metastasis, all of the patients had a prior history of primary or metastatic cancer and in eight patients there were other organ metastases. In one patient (No 4) the conjunctiva, iris, and choroid were the first sites of clinically apparent metastases and 4 months later she developed widespread bone and pleural metastases. In another patient (No 8) the conjunctiva and iris remained the only site of metastasis for 18 months. The mean interval between the detection of the primary tumour

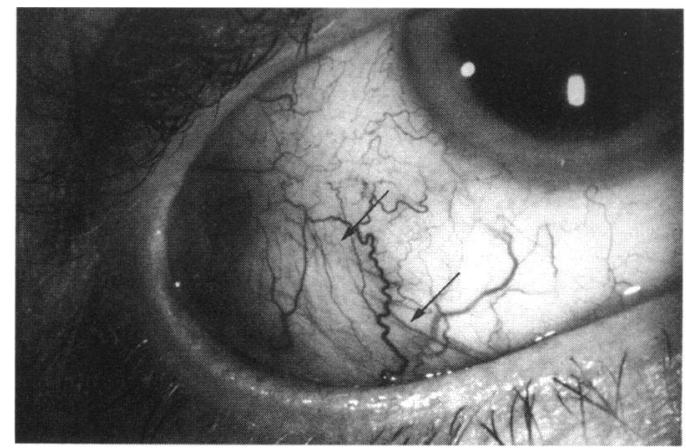

Figure 1 Red, solid conjunctival mass (arrows) with dilated vessels in the inferotemporal bulbar conjunctiva in a patient with metastatic breast carcinoma. and the conjunctival metastasis was 45 months (range 8-130 months).

Table 2 summarises the clinical ophthalmic presentation, treatment, and outcome for each patient. The chief complaint was red eye in four, foreign body sensation in two, visible mass in two, pain in one, and tearing in one patient. The visual acuity was $20 / 40$ or better in eight patients. In two patients the acuity was $20 / 80$ and hand movements, respectively due to concurrent iris metastases which produced extensive anterior chamber cells and secondary elevation of intraocular pressure. All 10 patients had unilateral involvement. In two patients (Nos 2 and 3) the conjunctiva was the only site of ocular and adnexal metastases. In three patients the iris was also involved and in four iris and posterior uvea were involved. Ipsilateral

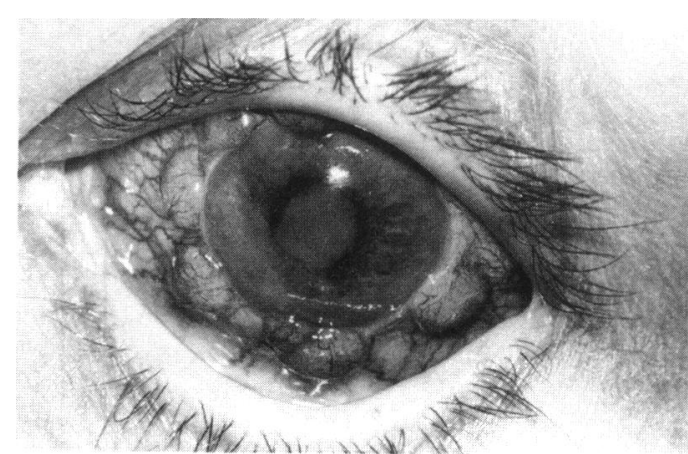

Figure 2 Multiple foci of metastatic cutaneous melanoma on the limbal conjunctiva. There is also an iris mass in the inferonasal quadrant. 
orbital metastases were present in two patients.

The conjunctival metastasis was unifocal in eight cases (Fig 1). In one patient (No 5) there were seven discrete foci of tumour (Fig 2) and in another (No 6) two separate tumours were visible. The tumour was located in the bulbar conjunctiva in six cases, in the palpebral conjunctiva in two, on the limbus and in the inferior forniceal conjunctiva in one each. The tumour was yellow in colour in seven cases, red in two, and brown in one.

The diagnosis of conjunctival metastasis was suspected clinically in all of these patients based on the history of cancer and evidence of systemic and other ocular metastasis. In two patients (Nos 2 and 3) with breast carcinoma in whom the conjunctival lesions were the only ocular signs, excisional biopsy established the diagnosis. In two cases (Nos 8 and 10) fine needle aspiration biopsy of the iris lesions was confirmed histopathologically.

The conjunctival metastasis was treated initially by external beam radiotherapy in seven patients. One patient was receiving chemotherapy for the widespread systemic disease at the time of ocular diagnosis. Two patients did not receive any treatment for the ocular disease as their systemic status deteriorated rapidly. A total dose of 3000-4000 cGy radiotherapy was implemented in divided doses. Four of the seven patients treated with radiation demonstrated excellent initial tumour regression, two showed no change, and one progressed. The eye that showed progression of the conjunctival and iris tumours was enucleated as a result of intractable pain and inflammation. The one patient treated with chemotherapy alone showed progression of the tumour.

After a mean follow up period of 8 months (range 2-26 months) nine patients died of systemic metastases. One patient (No 8) is still alive and free of other organ metastases 20 months after the ocular diagnosis. The mean time interval between diagnosis of the primary tumour and conjunctival metastasis was 44 months (range 8-130 months). The mean interval between conjunctival metastasis and death was 9 months (range 2-26 months). The mean interval between the diagnosis of the primary tumour and death was 59 months (range 10-141 months).

\section{Discussion}

Metastatic carcinoma of the conjunctiva is uncommon and is not even alluded to in most major clinicopathological series of metastatic cancer to the ocular region..$^{6-10}$ In an experimental model, Albert et al ${ }^{11}$ injected BrownPearce tumour cells into the left ventricles of rabbits and found only one conjunctival metastasis among 67 other ocular metastatic tumours produced by these cells. This rarity is further emphasised by a recent clinicopathological review of 2455 conjunctival lesions in adults, in which only one case of undifferentiated metastatic carcinoma was found. ${ }^{12}$ In a postmortem histopathological study of 716 eyes in patients who had cancer at the time of death, some patients were noted to have conjunctival metastases, albeit no further information on those particular cases is provided. ${ }^{1}$

Breast carcinoma accounts for the majority of intraocular and orbital metastases and this has been attributed to the longer survival time of these patients. ${ }^{34913}$ Metastasis of breast carcinoma usually occurs 2 to 5 years after the discovery of the primary tumour. ${ }^{13}$ Four of our patients had a history of treated breast carcinoma that metastasised to the conjunctiva after a mean period of 64 months, supporting the previous observations in the literature. Two similar patients were observed to develop conjunctival metastases following successful treatment of their primary tumours after 5 and 15 years respectively..$^{14} 15$

Metastatic bronchogenic carcinoma was found in two of our patients. In contrast with breast carcinoma, this malignancy has a propensity to metastasise before or shortly after its discovery. ${ }^{413}$ In our patients, conjunctival metastases developed 8 and 11 months after the detection of the primary tumours respectively. Conjunctival metastases have also been reported in patients having gastric adenocarcinoma, ${ }^{16}$ urinary bladder carcinoma, ${ }^{17}$ adenocarcinoma of the colon, ${ }^{18}$ and seminoma. ${ }^{19}$ Laryngeal carcinoma has not been reported previously.

Although uncommon, ocular metastases from cutaneous melanoma have been well documented. ${ }^{72021}$ Interestingly, most of the reported patients had their previously diagnosed primary cutaneous melanoma on their truncal skin and the primary lesions were classified as superficial spreading melanoma. ${ }^{721} 22$ Jakobiec et $a l^{7}$ reported five patients with conjunctival metastases that appeared 3 months to 1 year after the excision of the primary skin melanoma. The two patients with cutaneous melanoma in our series also had their primary neoplasm on their truncal skin but were classified as lentigo maligna Clark level 2 (patient No 5) and nodular types (patient No 6), and they metastasised to the conjunctiva after 71 months and 15 months respectively. This is not unexpected as the nodular variety is regarded as having the worst prognosis while the lentigo maligna type carries the best prognosis. ${ }^{21}$ Metastatic cutaneous melanoma may or may not be pigmented. ${ }^{23}$ In one series of patients with metastatic cutaneous melanoma, three had pigmented and two had non-pigmented lesions and all portions of the conjunctiva were the site of metastasis. ${ }^{7}$ In our two patients with metastatic melanoma the lesions were on the palpebral conjunctiva and pigmented in one and limbal, amelanotic, and multiple in the other.

Mansour and Hidayat $^{24}$ reported three patients with tarsal and palpebral conjunctival metastatic lesions but the majority of the reported cases suggest that the most common site of metastasis is the bulbar conjunctiva. ${ }^{14-17} 1922$ Review of the literature shows that most of the conjunctival metastases are solitary lesions with dilated overlying conjunctival vessels and not adherent to the underlying sclera. ${ }^{14-17} 1922$ Our 
findings are in concert with these observations; however, we did not encounter metastatic tumours with ulcerated surfaces protruding through the palpebral fissure with serosanguineous discharge that was reported in other cases. ${ }^{16-18}$

All of our patients had a known primary malignant tumour before the diagnosis of the conjunctival metastasis except one (No 10). This is similar to the metastatic tumours to the intraocular structures were the primary tumour is known in $73 \%$ of cases at the time of the ocular diagnosis. ${ }^{4}$ In 40 patients with metastatic tumours of the iris, $32.5 \%$ had no known primary tumours at the initial presentation. ${ }^{25}$ In a series of metastatic tumours to the eyelid, ${ }^{24}$ the lid lesions were detected before the primary focus in $45 \%$ of the cases and likewise metastatic tumours to the orbit have been found in $26 \%$ to occur before the discovery of the primary tumour. ${ }^{26}$ Concomitant other systemic metastases were present in $80 \%$ and other ocular metastases in $80 \%$ of our patients. This is similar to other reports. ${ }^{14-20} 22$ Interestingly, the most common associated ocular metastatic site was iris in $60 \%$ and the most common non-ocular site was subcutaneous tissues in $50 \%$ of our patients. This trend was not observed in previous reports.

Our experience suggests that the presence of a conjunctival mass in patients with known prior malignancy and associated ocular and systemic metastases in suggestive of a metastatic lesion. We elected to excise totally the lesions for both diagnostic and therapeutic purposes in two patients in whom the conjunctiva was the only involved ocular site. Regrowth of the tumour after excisional biopsy was noted by Hollander et al ${ }^{17}$ but we did not observe this in our cases. There is no single best management for conjunctival metastases. Many patients already receive chemotherapy for their systemic conditions which may provide local tumour control in the eye. Radiation alone showed variable results in conjunctival lesions but invariably caused regression of the concomitant iris or choroidal metastases in those particular patients. Patients with metastatic breast carcinoma to the conjunctiva showed regression after their radiation regimens. The conjunctival metastatic foci of patients with cutaneous melanoma and lung carcinoma were resistant to radiation and chemotherapy. Most of the reported patients with conjunctival metastases were managed by excisional biopsy, ${ }^{7} 1416-1822$ or radiotherapy. 1519

In summary, our experience with 10 patients with conjunctival metastases showed that similar to uveal, iris, and eyelid metastases, these lesions appear at a relatively advanced stage of the disease when other organ or ocular tissues are already involved. Although they usually do not threaten the vision or the integrity of the globe, treatment with external beam radiation or excisional biopsy depending on the systemic status of the patient may be advisable.

Supported by the Eye Tumor Research Foundation, Philadelphia, Pennsylvania, USA.

Presented at the American Academy of Ophthalmology Annual Meeting, San Francisco 1-3 November 1994.

1 Nelson CC, Hertzberg BS, Klintworth GK. A histopathologic study of 716 unselected eyes in patients with cancer at the time of death. Am f Ophthalmol 1983; 95 788-93.

2 Bloch RS, Gartner S. The incidence of ocular metastatic carcinoma. Arch Ophthalmol 1971; 85: 673-5.

3 Castro AP, Albert DM, Wang WI, Ni C. Tumors metastatic to the eye and adnexa. Int Ophthalmol Clin 1982; 38: 189-223.

4 Shields JA, Shields CL. Intraocular tumors. $A$ text and atlas. Philadelphia: WB Saunders, 1992: 207-38.

5 Shields JA, Shakin EP, Shields CL. Neoplasms metastatic to the eye and adnexa. In: Gold DH, Weingeist TA, eds. The eye in systemic disease. Philadelphia: JB Lippincott, 1990: eye in systemi

6 Ferry AP. Metastatic carcinoma of the eye and ocular adnexa. Int Ophthalmol Clin 1967; 7: 615-58.

7 Jakobiec FA, Buckman G, Zimmerman LE, La Piana FG, Levine MR, Ferry AP, et al. Metastatic melanoma within and to the conjunctiva. Ophthalmology 1989; 96: 999-1005.

8 Albert DM, Rubenstein RA, Scheie HG. Tumor metastasis to the eye: incidence in 213 adult patients with generalized malignancy. Am $\mathcal{f}$ Ophthalmol 1967; 63: 723-6.

9 Ferry AP, Font RL. Carcinoma metastatic to the eye and orbit. I. A clinicopathologic study of 227 cases. Arch Ophthalmol 1974; 92: 276-86.

10 Ferry AP, Font RL. Carcinoma metastatic to the eye and orbit. II. A clinicopathologic study of 26 patients with orbit. II. A clinicopathologic study of 26 patients with metastases to the anterior
Ophthalmol 1975; 93: 472-82.

11 Albert DM, Zimmerman AW, Zeideman I. Tumor metastasis to the eye. Part III. The fate of circulating tumor cells to the eye. Am $\mathcal{F}$ Ophthalmol 1967; 63: 733-8.

12 Grossniklaus HE, Green WR, Luckenbach M, Chan CC. Conjunctival lesions in adults. A clinical and histopathologic review. Cornea 1987; 6: 78-106.

13 Shields JA. Diagnosis and management of orbital tumors. Philadelphia: WB Saunders, 1989: 291-315.

14 Radnot M. Metastatic epibulbar carcinoma. Ophthalmology 1977; 74: 251-4.

15 Eichholtz W. Seltene metastasen im bereiche des auges. Klin Monatsbl Augenheilkd 1971; 158: 836-43.

16 Kuchle M, Holbach L, Schlotzer-Schrehardt U. Gastric adenocarcinoma presenting as an eyelid and conjunctival mass. Eur f Ophthalmol 1992; 2: 3-9.

17 Hollander A, Grots IA. Oculocutaneous metastases from carcinoma of the urinary bladder. Case report and review of the literature. Arch Derm 1968; 97: 678-84.

18 Ostriker PJ. Metastasis of adenocarcinoma of colon to conjunctival surface of lid. Arch Ophthalmol 1957; 57: 279-81.

19 Garret $M$. Ocular metastasis from seminoma. $\mathrm{Br} \mathcal{J}$ Ophthalmol 1959; 43: 753-61.

20 Font RL, Naumann G, Zimmerman LE. Primary malignant melanoma of the skin metastatic to the eye and orbit. $A m$ f Ophthalmol 1967; 63: 738-54.

21 Fishman ML, Tomaszewski MM, Kuwabara T. Malignant melanoma of the skin metastatic to the eye. Arch Ophthalmol 1976; 94: 1309-11.

22 Strempel I. Bindehautmetastase eines primaren hautmelanoms. Ophthalmologica $1982 ; 185: 52-7$.

23 Shields JA, Shields CL. Tumors of the conjunctiva and cornea. In: Smolin G, Thoft RA, eds. The cornea. Boston: Little, Brown, 1994: 579-95.

24 Mansour AM, Hidayat AA. Metastatic eyelid disease. Ophthalmology 1987; 94: 667-70.

25 Shields JA, Shields CL, Kiratli H, DePotter P. Metastatic tumors to the iris: personal experience with 40 cases. The 1994 JD Allen Lecture. Am $\mathcal{f}$ Ophthalmol (in press).

26 Shields CL, Shields JA, Peggs M. Tumors metastatic to the orbit. Ophthal Plast Reconstr Surg 1988; 4: 73-80. 